\title{
Collaborative learning in kindergarten: Challenge or reality?
}

\author{
Anaokullarında işbirlikli öğrenme: Zorluk mu yoksa gerçeklik mi?
}

\author{
Eleni Zisopoulou ${ }^{1}$
}

\section{Article History}

Received : 11 October 2018

Revised : 27 December 2018

Accepted : 18 April 2019

Online : 03 July 2019

\section{Article Type}

Research Article

\section{Makale Geçmişi \\ Geliş : 11 Ekim 2018 \\ Düzeltme : 27 Aralık 2018 \\ Kabul : 18 Nisan 2019 \\ Çevrimiçi : 03 Temmuz 2019}

\section{Makale Türü}

Araştırma Makalesi

\begin{abstract}
Collaborative learning is a twenty-first-century education trend with its main characteristic being the interaction among classmates. Collaborative learning in kindergarten, however, presents many difficulties, as preschoolers do not have advanced cooperation skills. As a result, teachers face challenges when applying this method. The study aimed to evaluate teachers' opinions about collaborative learning. The study's sample was composed of 107 kindergarten teachers in Greek schools. The tool was an improvised questionnaire that included personal characteristics of the sample, 14 multiple-choice questions on the application of collaborative learning and 33 questions regarding teachers' opinions about collaborative learning. Analysis of the data has shown that collaborative learning is frequently used in kindergarten schools, even though almost half of the teachers have never attended a relevant training course. In addition, teachers have highly evaluated the results of the method, which includes social and cognitive skills and the effects of collaborative learning evaluation and skills advancement.
\end{abstract}

Keywords: Collaborative learning; Teaching; Interaction; Kindergarten

Öz: İşbirlikli öğrenme, 21. Yüzyıldaki güncel eğitim konularından biridir. Işbirlikli öğrenmenin temel özelliği sınıf arkadaşları arasındaki etkileşimi içermesidir. Fakat anaokulunda işbirlikli öğrenme, okul öncesi çocukların ileri düzeyde işbirliği becerilerine sahip olmamaları nedeniyle birçok zorluğu beraberinde getirmektedir. Sonuç olarak, öğretmenler bu yöntemi uygularken zorluklarla karşılaşmaktadır. Araştırmada öğretmenlerin işbirlikli öğrenmeye ilişkin görüşlerini değerlendirmek amaçlanmıştır. Araştırmanın örneklemini Yunan okullarındaki 107 anaokulu öğretmeni oluşturmuştur. Veri toplama aracı olarak örneklemin kişisel özelliklerini, işbirlikçi öğrenmenin uygulanmasına ilişkin on dört çoktan seçmeli soruyu ve öğretmenlerin işbirlikli öğrenmeye ilişkin görüşlerine ilişkin otuz üç soruyu içeren bir anket kullanılmıştır. Verilerin analizi, öğretmenlerin neredeyse yarısının ilgili bir eğitime katılmamış olmamasına rağmen, anaokullarında işbirlikli öğrenmenin sıklıkla kullanıldığını göstermiştir. Ayrıca, öğretmenler sosyal ve bilişsel becerileri içeren yöntemin sonuçlarını ve işbirlikçi öğrenmeyi değerlendirme ve becerilerinin ilerlemesinin etkilerini yüksek derecede değerlendirmiştir.

Anahtar Kelimeler: İşbirlikli öğrenme; Öğretim; Etkileşim; Anaokulu

\footnotetext{
1 Aristotle University of Thessaloniki, Primary Education Management Body, e-mail: elzisop@yahoo.gr ORCID: https://orcid.org/0000-0003$\underline{3984-8458}$
}

\author{
Atıf için/To cite this article: \\ Zisopoulou, E. (2019). Collaborative learning in kindergarten: Challenge or reality?. Erken Cocukluk Calışmalar Dergisi, 3(2), 335-351. doi: \\ http://dx.doi.org/10.24130/eccd-jecs.1967201932113
}




\section{INTRODUCTION}

Social interplay in the classroom initially concerned the research community in the early 1950s and late 1960s, when Bales and Strodtbeck (1951) and Flanders (1970) investigated the interaction between the teacher and the pupils, as a whole group, rather than small groups in the classroom. This social interaction has led to a new education trend, called collaborative learning. Collaborative learning refers to several educational processes, the interaction among classmates being its main characteristic. However, the interaction between learners and teachers, or learners and place or learning material is also present in a collaborative learning environment (Dillenbourg, Järvelä, \& Fischer, 2009).

Nowadays, collaborative learning is a widely spread method used at every education level of formal teaching, as well as in informal teaching. Several studies have been conducted in order to investigate collaborative learning either at school (Tolmie et al., 2010; Häkkinen, Järvelä, Mäkitalo-Siegl, Ahonen, Näykki, \& Valtonen, 2015), at college (Bonk \& King, 2012; Barkley, Cross, \& Major, 2014), in higher education (Healey, 2014; Zheng, Niiya, \& Warschauer, 2015) or in adult education programmes (Nevin, Thousand, \& Villa, 2009; Sinha, Rogat, Adams-Wiggins, \& Hmelo-Silver, 2015). It is worth noting that this teaching method has recently drawn attention because of the extensive use of Information and Communication Technologies (ICTs) within the teaching process (Duță, \& Martínez-Rivera, 2015; Zhan, Fong, Mei, \& Liang, 2015).

However, literature that is related to collaborative learning in kindergarten is poor, especially when compared with other educational levels, even though preschool education is supposed to constitute the base of the educational system. Most studies investigate preschool collaborative learning in terms of learning through play (Jin \& Moran, 2017) or the use of computer technology (Said, Forret, \& Eames, 2013; García-Valcárcel Muñoz-Repiso, \& Caballero González, 2017). Nevertheless, the main aim of the majority of the studies conducted is skills development, such as language (BlumKulka, \& Dvir-Gvirsman, 2010) and mathematical-thinking development (Artut, 2009).

Another significant issue regarding this topic is the reflections of teachers on cooperative learning. Teachers are supposed to be the main keystone of the implementation of collaborative learning programmes and their opinions on the educational trend should be highlighted. Contrariwise, teachers' reflections on cooperative learning have been only slightly investigated in literature (Gillies \& Boyle, 2010; Hertz-Lazarowitz, 2008), and yet they have not been focused on kindergarten teachers. These studies presented the difficulties teachers confront through 
collaborative learning activities and the significant elements required for successful teaching through this method.

\section{Theoretical framework}

Collaborative learning has been the centre of discussion lately, but a commonly accepted definition of this term does not exist (Jenni \& Mauriel, 2004). This lack of a common definition raises the need to outline the basic characteristics of the term. A description that can approximately define collaborative learning is that it is an educational method in which the creation of groups that work together for an expected result is considered to be a prerequisite. A definition that agrees with this description is Cohen's (1994, p.3), who defined collaborative learning as '...students working together in a group small enough that everyone can participate on a collective task that has been clearly assigned'. Advantages and disadvantages of the method may affect its effectiveness, but it is a widespread method that helps learners and teachers in the learning process.

Peer interaction inside the classroom is the main characteristic of this method; discussion and cooperation can result in numerous benefits for the children, such as critical thinking, cognitive engagement and social skills advancement (Fawcett \& Garton, 2005). This kind of interaction can also help children broaden their minds and cultivate shared thinking (Dovigo, 2016). Furthermore, they have to defend their opinions, develop their self-esteem and advance their flexibility and their listening competency (Otto, 2014).

The concept of collaborative learning differentiates from the majority of typical learning methods, as it is not focused on a teacher-centred learning process, but on the communication among peers, with the teacher assuming the role of the manager and the facilitator (Laal \& Laal, 2012). Teachers in that case have to help children develop all those skills that will help them learn, without spoonfeeding them. In addition, teachers are responsible, especially through these kinds of techniques, for creating opportunities in order to furnish children with healthy social but also healthy emotional skills, such as empathy (Vasileiadou, 2009).

\section{OBJECTIVES and METHODS}

The main aim of this study was the evaluation of teachers' opinions on collaborative learning in kindergartens and how this learning method is applied more efficiently. Specifically, this survey focused on the teachers' reflections on the effectiveness of collaborative learning, including the necessary conditions and the ways for enhancing the implementation of the method. Furthermore, 
the study aimed to recognize the results of this learning method, focusing on the advancement of skills. The appraisal of teachers' difficulties and the evaluation of collaborative learning criteria was another purpose of this study.

\section{Participants}

The sample of this study consisted of 107 teachers from public and private kindergarten schools in the area of Central Macedonia, Greece. In this survey, the overwhelming majority were women, since only one participant out of 107 was male. The distribution of the sample was also unequal with regard to age, as 15 participants (14.2\%) were under 40 years old, 35 participants (33\%) were 41-45 years old, and 56 participants $(52.8 \%)$ were over 46 years old. Subsequently, the years of experience of the participants were distributed as follows: 26 teachers had under 15 years of experience, 39 teachers $(37.1 \%)$ had $16-20$ years of experience and finally, 40 teachers $(38.1 \%)$ had over 21 years of experience Two teachers did not answer the question regarding their years of experience.

In the question concerning the sample's education, teachers could give more than one answer. As a result, 100 people (93.5\%) answered that they have a bachelor's degree in preschool education. Twenty-one (19.6\%) of them had a master's degree and two participants held a $\mathrm{PhD}(1.9 \%)$. Thirteen participants $(12.1 \%)$ had a university degree from other faculties (primary education teachers, mathematicians, etc.), while 27 participants (25.2\%) took part in a simulation program, where they could become kindergarten teachers and 41 people $(38.3 \%)$ received recurrent training or attended a special teacher training course in classrooms with children from 4 to 6 years old.

\section{Measures}

For the aims of this study a questionnaire was designed, in order to investigate the application of collaborative learning in kindergarten schools. The quantitative method was selected as it was considered to be more appropriate for this type of study. The quantitative method has advantages that are related to the explicit description of the survey's objectives, the orientation of the variables of the study, dependent and independent, the high reliability of data and results and the objectivity of the extracted results (Matveet, 2002).

The questionnaire consisted of three parts: the first part included questions concerning the personal characteristics of the sample, such as gender, age and teaching experience. In the second part, there were 14 multiple-choice questions (most of them allowed more than one answers) examining the 
application of collaborative learning in the kindergarten where they work (for example, 'Which one(s) of the cooperative skills below bave you reinforced to yourpupils, in order to succeed in the effective application of the cooperative learning method?' and 'Which one(s) of the following factors affect the team's size during a collaborative learning activity?'). The third part consisted of 33 questions investigating the teachers' opinions on collaborative learning (for example, 'Common aims are considered to be a significant way of group support' and 'The improvement of social climate inside the classroom is considered to be a significant result of the cooperative learning process'). Answers were given on a 5 -point Likert scale with a positive orientation, from 1 to 5 (where $1=$ Strongly disagree and $5=$ Strongly agree). No negative questions were included in the questionnaire. Questions included in the questionnaire were based on the literature review on collaborative learning and relevant studies concerning teachers' opinions on this topic (Lopata, Miller, \& Miller, 2003; Baines, Blatchford, P., \& Kutnick, P., 2008).

A pilot study was conducted, in order to identify possible problems with the questionnaire. After the sample's comments and notifications, concerning mostly language issues, the questionnaire was revised and distributed to the main sample.

\section{Data collection}

This study took place in public and private kindergartens in the area of Central Macedonia from December 2017 to February 2018. The distribution of the questionnaires was carried out before the Christmas break, so that participants would have enough time to fill them out. The first page included the researcher's personal info, a guide for the completion of the questionnaire and one paragraph mentioning that questionnaires were anonymous and the participation was voluntary. The analysis of the data was conducted through the Statistical Package for Social Sciences (SPSS) version 22.

\section{RESULTS}

The main aim of this survey was to examine the application of collaborative learning in kindergartens and the teachers' opinions on this teaching method. For this reason, a number of questions were combined, in order to help the reader fully understand the field of collaborative learning in kindergarten schools.

\section{Application of collaborative learning in kindergarten}

The first question to the kindergarten teachers who took part in this survey intended to identify whether they had attended a training course on collaborative training. Of the 107 teachers, 65 
$(60.7 \%)$ answered positively to this question. Table 1 shows teachers' participation in a training course. Furthermore, 42 teachers $(64.6 \%)$ had received training on collaborative learning through a seminar, $27(41.5 \%)$ through a training programme offered by a school counsellor, while 26 participants $(40 \%)$ received training through a special teacher training course. The sample also noted that in 49 cases $(75.4 \%)$ this training was received in work groups and in 43 cases $(66.2 \%)$ the training was received through lectures or conferences. Finally, the majority of the participants (59 answers, 92.2\%) stated that the received training programme helped them apply collaborative learning in the classroom.

Table 1. Participation, source and type of training course on collaborative learning

\begin{tabular}{cccccc}
\hline $\begin{array}{c}\text { Participation in } \\
\text { training course }\end{array}$ & \multicolumn{2}{c}{ Source of training } & \multicolumn{2}{c}{ Type of training } \\
\hline YES & Seminar & $\begin{array}{l}\text { By a school } \\
\text { counsellor }\end{array}$ & $\begin{array}{c}\text { Special teacher } \\
\text { training course }\end{array}$ & $\begin{array}{c}\text { Work } \\
\text { groups }\end{array}$ & $\begin{array}{c}\text { Lecture or } \\
\text { conference }\end{array}$ \\
\cline { 2 - 6 } $65(60.7 \%)$ & $42(64.6 \%)$ & $27(41.5 \%)$ & $26(40 \%)$ & $49(75.4 \%)$ & $43(66.2 \%)$ \\
\hline $\begin{array}{c}\text { NO } \\
42(39.3 \%)\end{array}$ & & & & & \\
\hline
\end{tabular}

The next question concerned the application of collaborative learning in the classroom. Ninetyfive teachers $(89.6 \%)$ answered that they apply the collaborative method in the classroom, versus $11(10.4 \%)$ who answered that they do not use this method in the classroom. Moreover, the application of this method in most cases depends on the existence of the appropriate conditions, as 48 teachers $(52.2 \%)$ answered that they apply this method whenever the activity allows it. Nineteen teachers (20.7\%) answered that they use this method on a daily basis, while another 19 teachers $(20.7 \%)$ answered that they apply this method a few times during the week. Lastly, six teachers answered that they use this method a few times a month $(6.5 \%)$.

Table 2. Application of collaborative learning

\begin{tabular}{ccccc}
\hline $\begin{array}{l}\text { Application of } \\
\text { collaborative learning }\end{array}$ & $\begin{array}{l}\text { Application } \\
\text { whenever the } \\
\text { activity allows it }\end{array}$ & On a daily basis & $\begin{array}{c}\text { A few times } \\
\text { during the week }\end{array}$ & $\begin{array}{c}\text { A few times a } \\
\text { month }\end{array}$ \\
\hline $\begin{array}{c}\text { YES } \\
\mathbf{9 5}(\mathbf{8 9 . 6 \% )}\end{array}$ & $48(55.2 \%)$ & $19(20.7 \%)$ & $19(20.7 \%)$ & $6(6.5 \%)$ \\
\hline $\begin{array}{l}\mathbf{N O} \\
\mathbf{1 1}(\mathbf{1 0 . 4 \% )}\end{array}$ & & & \\
\hline
\end{tabular}

As for the activities teachers select in order to apply this learning method, the sample was divided in the area of language activities, since half of them (47 people, $50 \%$ ) answered that they use the collaborative method in language activities and the rest answered negatively to this question. 
Answers on mathematical activities also presented the same results, as 50 teachers $(53.2 \%)$ answered positively to this question, while 44 teachers $(46.8 \%)$ noted that they do not use the collaborative method in mathematical activities. Work plans is the activity that seems to be the most suitable for collaborative learning in kindergarten schools, as 77 teachers $(81.9 \%)$ answered positively, whereas 17 answers (18.1\%) were negative. Art, music and drama activities also appeared to be suitable for collaboration according to teachers, as 74 teachers $(78.7 \%)$ answered that they apply the collaborative method through these activities, versus 20 teachers $(21.3 \%)$ who answered negatively. Seventy-three teachers (77.7\%) also answered that they use collaborative teaching in spontaneous activities that take place in the classroom, while 21 teachers $(22.3 \%)$ noted that they avoid it.

Table 3. Type of activities in which collaborative learning is applied

\begin{tabular}{cccccc}
\hline Type of activities & $\begin{array}{c}\text { Language } \\
\text { activities }\end{array}$ & $\begin{array}{c}\text { Mathematical } \\
\text { activities }\end{array}$ & Work plans & $\begin{array}{c}\text { Art, music } \\
\text { and drama } \\
\text { activities }\end{array}$ & $\begin{array}{c}\text { Spontaneous } \\
\text { activities }\end{array}$ \\
\hline YES & $47(50 \%)$ & $50(53.2 \%)$ & $77(81.9 \%)$ & $74(78.7 \%)$ & $73(77.7 \%)$ \\
\hline NO & $47(50 \%)$ & $44(46.8 \%)$ & $17(18.1 \%)$ & $20(21.3 \%)$ & $21(22.3 \%)$ \\
\hline
\end{tabular}

Skills advancement is of great importance to the teachers in order to apply collaborative learning in the classroom. Thus, teachers answered that they have improved low-voice talking (50 people, $52.6 \%$ ), stay in the group (48 people, 50.5\%), mutual help (80 people, $84.2 \%$ ), group communication (81 people, $85.3 \%$ ), concentration on the exercise (54 people, $56.8 \%$ ) and listening skills (58 people, $54.2 \%$ ).

The effective application of collaborative learning depends greatly on how well prepared students are to join a group. As a result, teachers prepare children through group conversation (73 answers, $76.8 \%$ ), through collaborative group play (80 answers, $84.2 \%$ ) and through pro-collaborative activities (45 answers, 47.4\%), while only 2 teachers (2.1\%) answered they do not make any preparation with children at all before the application of collaborative learning.

Table 4. Skills advancement and preparation for effective collaborative learning in classroom

\begin{tabular}{|c|c|c|}
\hline $\begin{array}{l}\text { Collaborative learning } \\
\text { in classroom }\end{array}$ & & \\
\hline \multirow{6}{*}{ Skills advancement } & Low-voice talking & $50(52.6 \%)$ \\
\hline & Stay in group & $48(50.5 \%)$ \\
\hline & Mutual help & $80(84.2 \%)$ \\
\hline & Group communication & $81(85.3 \%)$ \\
\hline & Concentration on the exercise & $54(56.8 \%)$ \\
\hline & Listening skills & $58(54.2 \%)$ \\
\hline \multicolumn{3}{|c|}{$\begin{array}{r}\text { Erken Çocukluk Çalışmaları Dergisi } \\
\text { Cilt } 3 \cdot \text { Sayı } 2 \cdot \text { Ekim }\end{array}$} \\
\hline
\end{tabular}




\begin{tabular}{lll}
\hline & Group conversation & $73(76.8 \%)$ \\
\cline { 2 - 3 } $\begin{array}{l}\text { Children preparation for } \\
\text { collaborative learning }\end{array}$ & Collaborative group play & $80(84.2 \%)$ \\
\cline { 2 - 3 } & Pro- collaborative activities & $45(47.4 \%)$ \\
\cline { 2 - 2 } & No preparation & $2(2.1 \%)$ \\
\hline
\end{tabular}

It is worth noting that the number of members making up a group in a collaborative activity varies, since some participants choose to create groups of 2 (14 answers, 14.7\%), the same number of participants (14 answers, $14.7 \%$ ) prefer to create groups of 3, whereas 41 teachers $(43.2 \%)$ tend to create groups of 4 when they perform a collaborative activity. However, the majority of the participants answered that the number of group members depends on the nature of the activity (63 answers, $66.3 \%$ ).

Table 5. Number of members in a collaborative activity

\begin{tabular}{lcccc}
\hline $\begin{array}{l}\text { Number of } \\
\text { members }\end{array}$ & Two members & Three members & Four members & $\begin{array}{c}\text { Depends on the } \\
\text { nature of activity }\end{array}$ \\
\hline & $14(14.7 \%)$ & $14(14.7 \%)$ & $41(43.2 \%)$ & $63(66.3 \%)$ \\
\hline
\end{tabular}

In addition, teachers believe that the number of members in a collaborative group is affected by the children's age (27 answers, 28.4\%), by the adequacy of teaching aids (34 answers, 35.8\%), by the number of children in the classroom (72 answers, $75.8 \%$ ), by the level of difficulty of specific activities (71 answers, 74.7\%) and by children's experience in collaborative learning (55 answers, $57.9 \%)$.

Table 6. Factors affecting members of a collaborative group

\begin{tabular}{cccccc}
\hline Factors & Children's age & $\begin{array}{c}\text { Adequacy of } \\
\text { teaching aids }\end{array}$ & $\begin{array}{c}\text { Number of } \\
\text { children in } \\
\text { classroom }\end{array}$ & $\begin{array}{c}\text { Level of } \\
\text { difficulty }\end{array}$ & $\begin{array}{c}\text { Children's } \\
\text { experience }\end{array}$ \\
\hline $27(28.4 \%)$ & $34(35.8 \%)$ & $72(75.8 \%)$ & $71(74.7 \%)$ & $55(57.9 \%)$ \\
\hline
\end{tabular}

Collaborative learning may present difficulties that depend mainly on children's cooperation. In many cases, children may be supplanted by other children (58 answers, 61.1\%) or they may not be able to apply the collaborative skills (53 answers, 55.8\%). Furthermore, in some cases children cannot communicate efficiently with the other members of the group defined by the teacher (52 answers, $54.7 \%$ ) or they do not agree on the presentation of their work (11 answers, 11.6\%). However, difficulties do not only emanate from learners themselves, but also from group composition (19 answers, 20\%), teaching design (27 answers, 28.4\%), aim achievement (30 
answers, 31.6\%), discipline enforcement (31 answers, 32.6\%) and simultaneous supervision of more than one group (77 answers, 81.1\%).

Table 7. Difficulties in collaborative learning activities

Difficulties in collaborative

learning activities

\begin{tabular}{|c|c|c|}
\hline \multirow{4}{*}{ Difficulties with children } & $\begin{array}{l}\text { Children supplanted by other } \\
\text { children }\end{array}$ & $58(61.1 \%)$ \\
\hline & $\begin{array}{l}\text { Children not able to apply } \\
\text { collaborative skills }\end{array}$ & $53(55.8 \%)$ \\
\hline & $\begin{array}{l}\text { Children cannot communicate } \\
\text { efficiently }\end{array}$ & $52(57.4 \%)$ \\
\hline & $\begin{array}{l}\text { Children do not agree on the } \\
\text { presentation of their work }\end{array}$ & $11(11.6 \%)$ \\
\hline \multirow{5}{*}{ Difficulties with other factors } & Group composition & $19(20 \%)$ \\
\hline & Teaching design & $27(28.4 \%)$ \\
\hline & Aim achievement & $30(31.6 \%)$ \\
\hline & Discipline enforcement & $31(32.6 \%)$ \\
\hline & $\begin{array}{l}\text { Simultaneous supervision of more } \\
\text { than one groups }\end{array}$ & $77(81.1 \%)$ \\
\hline
\end{tabular}

The main techniques that are used to enhance cooperation between learners during a collaborative activity are changing roles among children in a group (58 answers, 61.1\%), reteaching of group skills (46 answers, 48.4\%), changing group members (44 answers, 46.3\%) and redefining the target (51 answers, $53.7 \%$ ).

Table 8. Techniques for cooperation in collaborative learning activities

\begin{tabular}{ccccc}
\hline Techniques & Change of roles & $\begin{array}{c}\text { Reteaching of } \\
\text { group skills }\end{array}$ & $\begin{array}{c}\text { Change of group } \\
\text { members }\end{array}$ & Target redefining \\
\hline $58(61.1 \%)$ & $46(48.4 \%)$ & $44(46.3 \%)$ & $51(53.7 \%)$ \\
\hline
\end{tabular}

\section{Teachers' opinions on collaborative learning and teaching}

The third part of the questionnaire used for this study consisted of questions that aimed to evaluate participants' opinions on collaborative learning. Exploratory factor analysis with rectangular axis rotation (Varimax) was conducted, which excluded five items, because either they loaded in two factors or in none of them. The factor analysis extracted an eight-factor solution, which accounted for $78.53 \%$ of total variance. As a result, items with a value greater than .4 loaded in each of the following factors: collaborative learning as an effective learning method (3 items); necessary 
conditions for collaborative learning (5 items); expected social skills ( 3 items); expected cognitive skills (4 items); teachers' difficulties in collaborative teaching (3 items); enhancing ways of applying collaborative learning ( 4 items); significant results of collaborative teaching ( 3 items); and evaluating the criteria for collaborative learning (3 items). Also, reliability analysis was conducted in this questionnaire, which showed a high reliability (Cronbach $\alpha=0.0952)$. Means and standard deviations are presented in Table 9.

Table 9. Factors' mean and standard deviation

\begin{tabular}{lllc}
\hline $\mathbf{N}$ & \multicolumn{1}{c}{ Factor } & Mean & Standard Deviation \\
\hline 1 & $\begin{array}{l}\text { Collaborative learning as an effective } \\
\text { learning method (3 items) }\end{array}$ & 4.35 & 0.61 \\
\hline 2 & $\begin{array}{l}\text { Necessary conditions for collaborative } \\
\text { learning (5 items) }\end{array}$ & 4.18 & 0.55 \\
\hline 3 & Expected social skills (3 items) & 4.24 & 0.58 \\
\hline 4 & Expected cognitive skills (4 items) & 4.14 & 0.66 \\
\hline 5 & $\begin{array}{l}\text { Teachers' difficulties in collaborative } \\
\text { teaching (3 items) }\end{array}$ & 3.85 & 0.85 \\
\hline 6 & $\begin{array}{l}\text { Enhancing ways of applying collaborative } \\
\text { learning (4 items) }\end{array}$ & 4.20 & 0.67 \\
\hline 7 & $\begin{array}{l}\text { Significant results of collaborative teaching } \\
\text { (3 items) }\end{array}$ & 4.22 & 0.56 \\
\hline 8 & $\begin{array}{l}\text { Evaluating the criteria for collaborative } \\
\text { learning (3 items) }\end{array}$ & 4.22 & 0.68 \\
\hline & & & \\
\hline
\end{tabular}

Subsequently, an analysis of variance was carried out (ANOVA) in order to find out whether the factors above were influenced by other factors, such as age or experience. In the first case, analysis was conducted with the seven aforementioned factors acting as dependent factors and age acting as an independent factor. Results did not show any statistically significant differences.

In the second case, analysis was conducted with the seven aforementioned factors acting as dependent factors and experience acting as an independent factor. The results revealed that experience affected six out of eight factors in this survey: necessary conditions for collaborative learning; expected social skills; expected cognitive skills; enhancing ways of applying collaborative learning; significant results of collaborative learning, and evaluating the criteria for collaborative learning. Necessary conditions for collaborative learning showed a statistically significant difference $(F(4,98)=2.722, p=.012)$, as people with more than 21 years of teaching experience evaluated the necessary conditions for collaborative learning as more significant $(M=4.37$, S.D. $=0.46)$ than the other experience groups $(1-15$ years: $M=4.18$, S.D. $=0.46,15-20$ years: $\mathrm{M}=4.08$, S.D. $=0.63)$. 
A statistically significant difference was also found in the factor expected social skills $(F(4,100)=3.416$, $p=.000$ ). Teachers with 1 to 15 years of experience evaluated the level of significance of social skills gained through collaborative learning as lower $(M=4.01, S . D .=0.54)$ than the other two groups (15-20 years: $M=4.22$, S.D. $=0.60$, over 21 years: $M=4.44$, S.D. $=0.54)$. As before, teachers with over 21 years of experience noted the highest score in this factor.

Expected cognitive skills was a factor greatly influenced by the years of experience $(F(4,98)=3.555$, $p=.000)$. Once again, participants' experience was proportionate to expected cognitive skills $(1-15$ years: $\mathrm{M}=3.93$, S.D. $=0.58,16-20$ years: $\mathrm{M}=3.72$, S.D. $=0.92$, over 21 years: $\mathrm{M}=4.00$, S.D. $=0.87$ ).

The factor enbancing ways of applying collaborative learning was affected by teachers' experience, as analysis showed a statistically significant difference $(F(4,98)=1.696, p=.026)$. In this factor too, teachers with more years of experience (over 21 years) evaluated the enhancing ways of applying collaborative learning as more significant $(M=4.41$, S.D. $=0.54)$ than other experience groups $(1-15$ years: $\mathrm{M}=4.09$, S.D. $=0.57,15-20$ years: $\mathrm{M}=4.05$, S.D. $=0.79)$.

The factor significant results of collaborative learning was also affected by years of experience, since analysis of variance showed a statistically significant difference $(F(2,97)=1.037, p=.033)$. Teachers with 1-15 years of experience evaluated the results of collaborative learning in the classroom as less significant $(M=4.10, S . D .=0.53)$ than the other experience groups $(16-20$ years: $M=4.11$, S.D. $=0.61$, over 21 years: $\mathrm{M}=4.41$, S.D. $=0.47)$.

Finally, the factor evaluating the criteria for collaborative learning appeared to be influenced by experience, as the analysis also showed a statistically significant difference $(F(4,100)=1.441, p=.028)$. Years of experience seem to be proportionate in this case too, as people with less years of experience assessed the evaluating criteria for collaborative learning as less important, whereas people with more years of experience scored higher rates in this field $(1-15$ years: $M=4.05$, S.D. $=0.59,16-20$ years: $\mathrm{M}=4.10$, S.D. $=0.73$, over 21 years: $\mathrm{M}=4.43$, S.D. $=0.63$ ).

Table 10. Results of ANOVA between factors and experience categories

\begin{tabular}{|c|c|c|c|c|}
\hline Factor & & df & $\mathbf{F}$ & Sig. \\
\hline \multirow{2}{*}{ Necessary conditions for collaborative learning } & Between Groups & 4 & \multirow{2}{*}{2.722} & \multirow{2}{*}{0.012} \\
\hline & Within Groups & 98 & & \\
\hline \multirow{2}{*}{ Expected social skills } & Between Groups & 4 & \multirow{2}{*}{3.416} & \multirow{2}{*}{0.006} \\
\hline & Within Groups & 100 & & \\
\hline \multirow{2}{*}{ Expected cognitive skills } & Between Groups & 4 & \multirow{2}{*}{3.555} & \multirow{2}{*}{0.000} \\
\hline & Within Groups & 99 & & \\
\hline \multirow{2}{*}{ Enhancing ways of applying collaborative learning } & Between Groups & 4 & \multirow{2}{*}{1.696} & \multirow{2}{*}{0.026} \\
\hline & Within Groups & 98 & & \\
\hline
\end{tabular}




\begin{tabular}{|c|c|c|c|c|}
\hline \multirow{2}{*}{ Significant results of collaborative teaching } & Between Groups & 2 & \multirow{2}{*}{1.037} & \multirow{2}{*}{0.033} \\
\hline & Within Groups & 97 & & \\
\hline \multirow{2}{*}{ Evaluating the criteria for collaborative learning } & Between Groups & 4 & \multirow{2}{*}{1.441} & \multirow{2}{*}{0.028} \\
\hline & Within Groups & 100 & & \\
\hline
\end{tabular}

Lastly, an independent-sample T-test analysis was conducted in order to detect possible statistically significant differences among the factors examined in this survey and question five 'Have you ever been trained in collaborative learning?'. Analysis showed that people who had received training in collaborative learning did not have any differences from those who had not received similar training.

\section{DISCUSSION}

Collaborative learning in kindergarten seems to be a difficult task for the teacher as children at that age are egocentric by nature and, as a result, not mature enough to possess the skills needed for group teaching (Jacobs, 2017). Nevertheless, teachers find collaborative learning an interesting method even for preschoolers, as it enhances skills and abilities that will prove to be useful for the rest of their lives (Alanís, 2018).

This study, which took place in public and private kindergarten schools in the area of Central Macedonia, unearthed the field of collaborative learning in preschool teaching in Greece. The results of this survey showed that training in collaborative learning is not obligatory, since teachers chose to follow such a training programme. Nevertheless, there are teachers who apply this educational method, even though they have not received such training. International literature has shown that the majority of training in collaborative learning takes place at university, where students learn how to apply this method in a classroom setting (Guasch, Alvarez, \& Espasa, 2010).

The study also showed that collaborative learning is most suitable for spontaneous activities, or art and music activities in a classroom. Technology advancement, though, has changed the field and nowadays, the use of ICTs is the focal point of collaborative learning and teaching (Larusson \& Alterman, 2009). The great influence technology has on today's collaborative teaching does not necessarily exclude the application of this method in art activities inside and outside the traditional education system (Richardson, 2010).

However, the main finding of this study seems to be the major role that preschoolers' communication skills play in the efficiency of collaborative learning. In literature, there is a wealth of articles supporting this finding (Kultti \& Pramling, 2015). Indeed, communication skills are found to be the key to many activities during preschool years, such as mathematics (Rudd, Lambert, 
Satterwhite, \& Smith, 2009), music (Strait, Parbery-Clark, O’Connell, \& Kraus, 2013) and language activities (Brassart \& Schelstraete, 2015). Enhancement of communication skills has also been found to help preschoolers with disabilities in the advancement of language or other cognitive abilities, but also in the advancement of social skills (Clark \& McDonnell, 2008).

Communication skills are only one requirement for the application of efficient collaborative learning in kindergartens. This study has shown that there are a lot of skills that teachers need to teach their pupils, in order to efficiently work in a collaborative classroom environment. For this reason, there are a lot of initiatives for promoting social and emotional skills in preschoolers, in order to build a strong foundation for the rest of their lives (Morris, Mattera, Castells, Bangser, Bierman, \& Raver, 2014). Besides, by practising several skills with their students, such as sharing, fulfilling individual responsibilities and listening to the speaker, teachers aim to improve not only the group, but also each pupil separately (Tarim, 2009).

Nowadays, teachers are more open to new, unconventional activities through learning processes, a fact that partially derives from globalization and the rapid development of technology. Job characteristics, but also personal circumstances may affect this trend (Lohman, 2006). This is why teachers find collaborative teaching and learning to be a very effective method, with positive benefits to preschoolers (acquisition of social and cognitive skills, enhancement of self-esteem, etc. as the findings of this survey revealed. This may also be a reason why teachers underestimate the difficulties that they confront during a collaborative activity, as the advantages are more significant for the learning process and, subsequently, the children.

It is worth mentioning that in this research, teachers with more years of experience evaluated certain characteristics of collaborative learning, such as social and cognitive skills, skills enhancement and evaluation criteria, more highly than colleagues with less years of experience. Since experience and age are two interrelated elements, younger people might be expected to be more open to such learning activities. However, in this case, younger teachers may have not been familiar enough with cooperative activities and for this reason they assessed them with a lower score.

Early childhood education is a level of education that faces many problems due to the receivers' nature and immaturity. Therefore, there should be a focus by governments generally, and specifically in Greece, which bears a financial crisis, with subsequent problems in the quality of such services (Stellakis, 2018). New trends and methods, like collaborative learning, should be promoted in order to elevate the quality level of early education in every country. 
The literature is lacking in studies related to the collaborative learning method in kindergarten. Nevertheless, kindergarten is an educational level in which cooperation must be promoted in order to be consolidated in pupils' skills. The results of this study can help state decision-makers recognize the situation related to collaborative learning and promote the conducting of respective programmes. Also, this survey can contribute to the gap in the literature regarding collaborative learning in preschool and constitutes the base for further research on the topic.

\section{Conclusion}

This research was conducted in order to examine the field of collaborative learning in kindergartens in Greece. The findings showed that this method is often used by kindergarten school teachers, as it provides a lot of benefits to preschoolers as well as to the learning process. The activities that are subject to collaborative learning are several (language, mathematics, art) and help children develop social, cognitive and emotional skills that will be useful in their lives.

Moreover, teachers highly evaluated the aspects of collaborative learning in this study. Some of the factors of collaborative learning, though, were found to be influenced by personal characteristics, such as age and experience, but not by the teacher's participation in a relevant training programme.

Among the limitations of the study was the totally uneven number of men and women, the uneven number of participants in each age group and their teaching experience. Furthermore, the questionnaire was developed by the writer, therefore a pilot study was conducted previously. Lastly, the questionnaire included self-report items that render the answers subjective.

A suggestion for future study could be the conduct of a qualitative study, where the researcher, through observation, could identify the advantages of collaborative learning in children. Additionally, research could be conducted that also involves parents and teachers, in order to find out the benefits of collaboration.

\section{REFERENCES}

Alanís, I. (2018). Enhancing collaborative learning: Activities and structures in a dual language preschool classroom. Association of Mexican American Educators Journal, 12(1), 5-26.

Artut, P. D. (2009). Experimental evaluation of the effects of cooperative learning on kindergarten children's mathematics ability. International Journal of Educational Research, 48(6), 370-380. 
Baines, E., Blatchford, P., \& Kutnick, P. (2008). Pupil grouping for learning: Developing a social pedagogy in the classroom. In R. Gillies, A. Ashman, \& J. Terwel (Eds.), The teacher's role in implementing cooperative learning in the classroom (pp. 55-71). New York: Springer.

Bales, R. F., \& Strodtbeck, F. L. (1951). Phases in group problem-solving. The Journal of Abnormal and Social Psychology, 46(4), 485-495.

Barkley, E. F., Cross, K. P., \& Major, C. H. (2014). Collaborative learning techniques: A handbook for college faculty. San Fransisco: John Wiley \& Sons.

Blum-Kulka, S., \& Dvir-Gvirsman, S. (2010). Peer interaction and learning. In P. P. B. McGaw (Ed.), International encyclopedia of education (3rd ed., pp. 444-449). Oxford, England: Elsevier.

Bonk, C. J., \& King, K. S. (2012). Models of asynchronous computer conferencing for collaborative learning in large college classes. In Electronic Collaborators (pp. 193-218). Routledge.

Brassart, E., \& Schelstraete, M. A. (2015). Enhancing the communication abilities of preschoolers at risk for behavior problems: Effectiveness of a parent-implemented language intervention. Infants \& Young Children, 28(4), 337-354.

Clark, C., \& McDonnell, A. P. (2008). Teaching choice making to children with visual impairments and multiple disabilities in preschool and kindergarten classrooms. Journal of Visual Impairment \& Blindness, 102(7), 397-409.

Cohen, E. G. (1994). Restructuring the classroom: Conditions for productive small groups. Review of Educational Research, 64(1), 1-35.

Dillenbourg, P., Järvelä, S., \& Fischer, F. (2009). The evolution of research on computer-supported collaborative learning. In Technology-enhanced Learning (pp. 3-19). Dordrecht: Springer,.

Dovigo, F. (2016). Argumentation in preschool: A common ground for collaborative learning in early childhood. European Early Childhood Education Research Journal, 24(6), 818-840.

Duță, N., \& Martínez-Rivera, O. (2015). Between theory and practice: The importance of ICT in higher education as a tool for collaborative learning. Procedia-Social and Behavioral Sciences, 180, 1466-1473.

Fawcett, L. M., \& Garton, A. F. (2005). The effect of peer collaboration on children's problem solving ability. British Journal of Education Psychology, 75, 157-169.

Flanders, N. A. (1970). Analyzing teacher behavior (pp. 100-107). Addison-Wesley P. C.

Gillies, R. M., \& Boyle, M. (2010). Teachers' reflections on cooperative learning: Issues of implementation. Teaching and Teacher Education, 26(4), 933-940.

González, Y. A. C., \& Muñoz-Repiso, A. G. V. (2017). Development of computational thinking and collaborative learning in kindergarten using programmable educational robots: A teacher training experience. In Proceedings of the 5 th International Conference on Technological Ecosystems for Enhancing Multiculturality (p. 5). ACM. 
Guasch, T., Alvarez, I., \& Espasa, A. (2010). University teacher competencies in a virtual teaching/learning environment: Analysis of a teacher training experience. Teaching and Teacher Education, 26(2), 199-206.

Häkkinen, P., Järvelä, S., Mäkitalo-Siegl, K., Ahonen, A., Näykki, P., \& Valtonen, T. (2015). Preparing teacher students for $21^{\text {st }}$-century learning practices (PREP 21): A framework for enhancing collaborative problem solving and strategic learning skills. Retrieved from https://www.researchgate.net/profile/Paivi_Haekkinen/publication/304991970 Prepari ng teacher-students for twenty-firstcentury learning practices PREP 21 a framework for enhancing collaborative probl em-solving and strategic learning skills/links/579f53b808ae80bf6ea7b212.pdf

Healey, M. (2014). Students as partners in learning and teaching in higher education. In Workshop Presented at University College Cork (Vol. 12, p. 15).

Hertz-Lazarowitz, R. (2008). Beyond the classroom and into the community: the role of the teacher in expanding the pedagogy of cooperation. In R. Gillies, A. Ashman, \& J. Terwel (Eds.), The teachers' role in implementing cooperative learning in the classroom (pp. 37-54). New York: Springer.

Jacobs, E. (2017). The privacy behaviour of preschool children: Mechanisms and functions in the day-care environment. In Paul F. Wilkinson, In celebration of play (pp. 119-134). Routledge.

Jenni, R. W. \& Mauriel, J. (2004). Cooperation and collaboration: Reality or rhetoric? International Journal of Leadership in Education, 7(2), 181-95.

Jin, M., \& Moran, M. J. (2017). Understanding preschool children's cooperative problem solving during play: China and the US. In James and Cobanoglu (Eds.), Global Conference on Education and Research (GLOCER 2017) (p. 213).

Kultti, A., \& Pramling, N. (2015). Limes and lemons: Teaching and learning in preschool as the coordination of perspectives and sensory modalities. International Journal of Early Childhood, 47(1), 105-117.

Laal, M., \& Laal, M. (2012). Collaborative learning: What is it?. Procedia-Social and Behavioral Sciences, 31, 491-495.

Larusson, J. A., \& Alterman, R. (2009). Wikis to support the "collaborative" part of collaborative learning. International Journal of Computer-Supported Collaborative Learning, 4(4), 371-402.

Lohman, M. C. (2006). Factors influencing teachers' engagement in informal learning activities. Journal of Workplace Learning, 18(3), 141-156.

Lopata, C., Miller, K., \& Miller, R. (2003). Survey of actual and preferred use of cooperative learning among exemplar teachers. The Journal of Educational Research, 96, 232-241.

Matveev, A. V. (2002). The advantages of employing quantitative and qualitative methods in intercultural research: Practical implications from the study of the perceptions of intercultural communication competence by American and Russian managers. Theory of Communication and Applied Communication, 1(1), 59-67. 
Morris, P., Mattera, S., Castells, N., Bangser, M., Bierman, K., \& Raver, C. C. (2014). Impact findings from the Head Start CARES demonstration: National evaluation of three approaches to improving preschoolers' social and emotional competence. OPRE Report, 2014. 44. Retrieved from bttps://files.eric.ed.gov/fulltext/ED546649.pdf

Nevin, A. I., Thousand, J. S., \& Villa, R. A. (2009). Collaborative teaching for teacher educators: What does the research say? Teaching and Teacher Education, 25(4), 569-574.

Otto, B. (2014). Language development in early childhood. Upper Saddle River, NJ: Pearson.

Richardson, J. (2010). Interventionist art education: Contingent communities, social dialogue, and public collaboration. Studies in Art Education, 52(1), 18-33.

Rudd, L. C., Lambert, M. C., Satterwhite, M., \& Smith, C. H. (2009). Professional development+ coaching $=$ enhanced teaching: Increasing usage of math mediated language in preschool classrooms. Early Childhood Education Journal, 37(1), 63-69.

Said, M. N. H. B. M., Forret, M., \& Eames, C. (2013). Online collaborative learning in tertiary ICT education: Constraints and suggestions for improvement. In 2013 International Conference on Informatics and Creative Multimedia (pp. 153-158). IEEE.

Sinha, S., Rogat, T. K., Adams-Wiggins, K. R., \& Hmelo-Silver, C. E. (2015). Collaborative group engagement in a computer-supported inquiry learning environment. International Journal of Computer-Supported Collaborative Learning, 10(3), 273-307.

Stellakis, N. (2018). Access to and quality of early childhood education and care in Greece. Journal of Early Childhood Studies, 2(1), 151-171.

Strait, D. L., Parbery-Clark, A., O’Connell, S., \& Kraus, N. (2013). Biological impact of preschool music classes on processing speech in noise. Developmental Cognitive Neuroscience, 6, 51-60.

Tarim, K. (2009). The effects of cooperative learning on preschoolers' mathematics problemsolving ability. Educational Studies in Mathematics, 72(3), 325-340.

Tolmie, A. K., Topping, K. J., Christie, D., Donaldson, C., Howe, C., Jessiman, E., Livingston, K., \& Thurston, A. (2010). Social effects of collaborative learning in primary schools. Learning and Instruction, 20(3), 177-191.

Vasileiadou, M. (2009). Cooperative learning and its effects on pre-primary, marginalized children. Emotional and Behavioural Difficulties, 14(4), 337-347.

Zhan, Z., Fong, P. S., Mei, H., \& Liang, T. (2015). Effects of gender grouping on students' group performance, individual achievements and attitudes in computer-supported collaborative learning. Computers in Human Behavior, 48, 587-596.

Zheng, B., Niiya, M., \& Warschauer, M. (2015). Wikis and collaborative learning in higher education. Technology, Pedagogy and Education, 24(3), 357-374. 